\begin{tabular}{c} 
CARADDE: Jurnal Pengabdian Kepada Masyarakat \\
$\begin{array}{c}\text { https://journal.ilininstitute.com/index.php/caradde } \\
\text { Volume 1 I Nomor 1 I Agustus | 2018 } \\
\text { e-ISSN: 2621-7910 dan p-ISSN: 2621-7961 } \\
\text { DOI: } \underline{\text { https://doi.org/10.31960/caradde.v1i1.19 }}\end{array}$ \\
\hline
\end{tabular}

\title{
Implementasi Model STM (Sains Teknologi Masyarakat) "Two In One" Dalam Pelatihan Pembuatan Media Ajar Fisika Berbasis Arduino Untuk Meningkatkan Kompetensi Guru Fisika Di Kabupaten Purworejo
}

\author{
Umi Pratiwi ${ }^{1}$ Sriyono $^{2}$
}

\begin{tabular}{ll}
\hline Keywords: & Abstrak. Permasalahan yang dihadapi guru-guru fisika \\
STM; CMS; & kabupaten Purworejo saat ini adalah penggunaan media \\
E-Learning; & ajaryang tidak sesuai dengan perkembangan jaman. Guru \\
Media ajar fisika; & Fisika masih banyak yang tidak mengerti atau tidak \\
Arduino. & memiliki pengetahuan bagaimana mendesain alat \\
& praktikum dengan memanfaatkan teknologi mikrokontroler \\
Corespondensi Author & dan sensor. Tujuan penelitian ini adalah memberikan \\
Pendidikan Fisika, Universitas & pelatihan pembuatan media ajar fisika menggunakan \\
Muhammaadiyah Purworejo & mikrokontroler Arduino dan sensor. Mitra dalam \\
Jl. K.H.A. Dahlan no.3 Purworejo & pengabdian ini adalah guru-guru fisika yang tergabung \\
Email: umipratiwi@umpwr.ac.id & dalam MGMP Fisika se-Kabupaten Purworejo yaitu, SMA \\
& N 1 Purworejo dan SMA Muhammadiyah Purworejo. \\
History Artikel & Metode penelitian yang digunakan adalah pelatihan dengan \\
Received: Juni-2018; & model STM (Sain Teknologi Masyarakat) two in one yang \\
Reviewed: Juli-2018 & mengintegrasikan antara pemrograman arduino sebagai \\
Accepted: Agustus-2018 & software dengan komponen elektronika sensor sebagai \\
Published: Agustus-2108 & hardwarenya. Hasil yang diperoleh bahwa 50 \% peserta \\
& pelatihan menyatakan pelatihan sangat bermanfaat dan 90 \\
& \% menyatakan untuk dilaksanakan kembali secara berkala. \\
& Pelatihan ini menambah wawasan dan kemampuan bagi \\
& peserta tentang materi media ajarberbasis arduino sebesar 25 \\
& \%. Diharapkan pelatihan ini dapat meningkatkan \\
kemampuan peserta dalam pengembangan media ajar lebih & \\
\hline \hline
\end{tabular}

This work is licensed under a Creative Commons Attribution

International License

\section{PENDAHULUAN}

Banyak guru dan calon guru dihadapkan kenyataan bahwa mereka tidak menguasai cara mendesain alat peraga pembelajaran fisika. Guru hendaknya bisa mendesain dan membuat alat praktik sendiri sebagai media ajarnya. Pemanfaatan mikrokontroler dalam dunia robotika dan kontrol otomatis dapat digunakan sebagai bahan pembuat alat praktik. Mikrokotroler yang salah satu digunakan adalah Arduino, sebagai salah satu mikrokontroler yang banyak dinilai kemudahannya. saat ini bisa dimanfaatkan dengan baik dan mudah oleh para guru khususnya guru fisika. Pemanfaatan alat peraga pembelajaran berbasis mikrokontroler menghasilkan kefektifan pembelajaran dan meningkatkan motivasi belajar siswa (Rochayati dan Suprapto, 2017). 
Pembelajaran alat peraga berbasis arduino juga sangat layak digunakan sebesar 82,10\% untuk meningkatakan motivasi mahasiswa (Wijaya, dkk, 2017). Selain itu juga alat eksperimen berbasis komputer dapat meningkatkan pemahaman siswa terhadap materi yang dipelajari dengan hasil tes yang tinggi (Musik, 2017).

Permasalahan yang dihadapi oleh para guru fisika Kab. Purworejo menurut narasumber selaku ketua MGMP Fisika kab.Purworejo menyatakan bahwa, para guru memiliki pemahaman dan informasi yang minim tentang software dan hardware instrumentasi elektronika berbasis mikrokontroler dan pemanfaatan sensor untuk membantu proses pembelajaran fisika terutama sebagai alat bantu laboratorium fisika. Menurut penelitian lebih lanjut oleh Bouquet dan Bobroff (2017) bahwa siswa diberi kebebasan untuk mengembangkan proyek berbasis hardware open source yang terjangkau harganya menggunakan arduino menghasilkan kemampuan kreativitas siswa dalam menciptakan eksperimen fisika realistis.

Berdasarkan hal tersebutlah, perlu dilakukan pengembangan dan pelatihan bagi guru-guru fisika kab. Purworejo tentang penggunaan software dan hardware (two in one) untuk membantu proses pembelajaran fisika dan peningkatan kualitas pembelajaran fisika. Kolaborasi software dan hardware dalam bentuk "Two in One" yaitu pemanfaatan media ajar berbasis CMS web exe mampu menjadi media ajar e-learning yang baik yang melibatkan pemrograman arduino (Risdanto, 2013) dan pemanfaatan media ajar berbasis mikrokontroler arduino menjadikan pembelajaran yang efektif (Rochayati dan Suprapto, 2017). Solusi ini kami gunakan pendekatan STM (pendekatan Sains dan teknologi untuk masyarakat) berbasis, pendampingan dan konsultasi sampai terpenuhi tujuan pelatihan kemampuan pedagogik yang diperlukan baik softskill maupun hardskill sebagai bekal dan persiapan dalam pengajaran dikelas (Pratiwi dan Nurhidayati, 2016).

Menguasai pengetahuan seputar mikrokontroler dan teknologi sensor bagi guru fisika dapat dimanfaatkan sebagai bahan pembuat alat peraga atau media ajar bagi guru fisika. Secara umum kesulitan-kesulitan yang dialami guru fisika dalam membuat media ajar dengan pemanfaatan mikrokontroler sebagai bahan pembuatan media ajar adalah sebagai berikut: guru fisika memiliki pengetahuan yang rendah mengenai pemanfaatan mikrokontroler dan teknologi sensor sebagai bahan pembuatan media praktik atau media ajar pada mata pelajaran fisika, guru fisika banyak yang belum mengerti penggunaan teknologi mikrokontroler dan sensor sebagai media ajar fisika sehingga diperlukan suatu pelatihan pengenalan pembuatan dan pengolahan media ajar berbasis mikrokontroler yang mudah, murah, efektif dan efisien

Berbagai persoalan diatas sangat berpengaruh terhadap proses pembelajaran fisika. Oleh karena itu ditawarkan sebuah solusi untuk Meningkatkan Kompetensi Guru Fisika Dengan implementasi model STM (Sains Teknologi Masyarakat) Two in One dalam pelatihan pembuatan media ajar fisika berbasis arduino untuk eningkatkan kompetensi guru fisika di Kabuaten Purworejo. Sehingga diharapkan dengan adanya pelatihan dan pendampingan ini guru fisika Kab. Purworejo meningkat kompetensinya dan semakin berkualitas pembelajarannya.

Pendekatan STM didasari oleh pembelajaran aktif peserta didik, keterampilan proses pembelajaran, kontekstual dan nilai yang sedang berkembang dimasyarakat. Pendekatan STM Multistrategis ini mengaitkan antara sains teknologi dengan kebutuhan masyarakat dalam hal ini sesuai kebutuhan guru (Anna dan Suwarma 2015). Pendekatan Sains Teknologi Masyarakat merupakan pendekatan pembelajaran yang pada dasarnya membahas penerapan sains dan teknologi dalam konteks kehidupan manusia sehari-hari (Mulichah, 2006; Pratiwi dan Nurhidayati, 2016). Oleh karena itu pendekatan Sains Teknologi Masarakat disebut juga sebagai pendekatan terpadu antara sains dan isu teknologi yang ada dimasyarakat. Dengan pendekatan ini siswa dikondisikan agar mau dan mampu menerapkan prinsip sains untuk menghasilkan karya sederhana atau solusi pemikiran untuk mengatur dampak negatif yang mungkin timbul akibat munculnya produk teknologi. 
Menurut Nasional Science Teacher Association (NSTA) (Poedjiadi, 2010) menyatakan bahwa STM membentuk peserta didik dalam hal ini guru Fisika dengan keterampilan yang dapat menyebabkan mereka menjadi warga negara yangaktif dan peduli terhadap isu-isu yang member dampak terhadap lingkungannya atau kondisi mereka tinggal. Masih menurut Poedjiadi hal tersebut sejalan dengan tujuan pendidikan nasional tercantum dalam GBHN 1993, antara lain menghendaki agar dapat diciptakan insaninsan yang berperilaku kreatif. Penerapan STM berbasis pendekatan nilai yang dimaksud mengoptimalkan semua potensi dan perilaku yang diperlukan untuk menyelesaikan masalah, untuk mengadakan inovasi dan pengambilan keputusan berdasarkan nilai yang berkembang dalam masyarakat, sesuai karakteristik sosial, budaya, dan agamanya. Dalam penelitian ini difokuskan pada pendekatan sains untuk mengembangkan sikap ilmiah.
Penerapan STM berbasis TIK dan web exe dalam bentuk pelatihan, pembimbingan, pendampingan dan konsultasi sampai terpenuhi criteria standar minimal kemampuan pedagogik yang diperlukan baik softskill maupun hardskill sebagai bekal dan persiapan dalam pengajaran dikelas (Pratiwi dan Nurhidayati, 2016; Warjana dan Razaq, 2008). Gambaran masalah, solusi dan target luaran yang diharapkan sebagai berikut: Masalah utama yang didapat adalah rendahnya kemampuan guru Fisika dalam menggunakan TIK (Teknologi Informasi dan Komunikasi) khususnya pemanfaatan teknologi mikrokontroler sebagai alat bantu ajar. Dari uraian masalah yang ditemukan, kami memberikan alternatif pemecahan/solusi yakni berupa pelatihan yang berkaitan dengan pembuatan dan pengolahan modul ajar berbasis mikrokontroler.

Berdasarkan penjelasan diatas, bagan gambaran masalah, solusi, dan target luaran dalam proposal ini adalah.

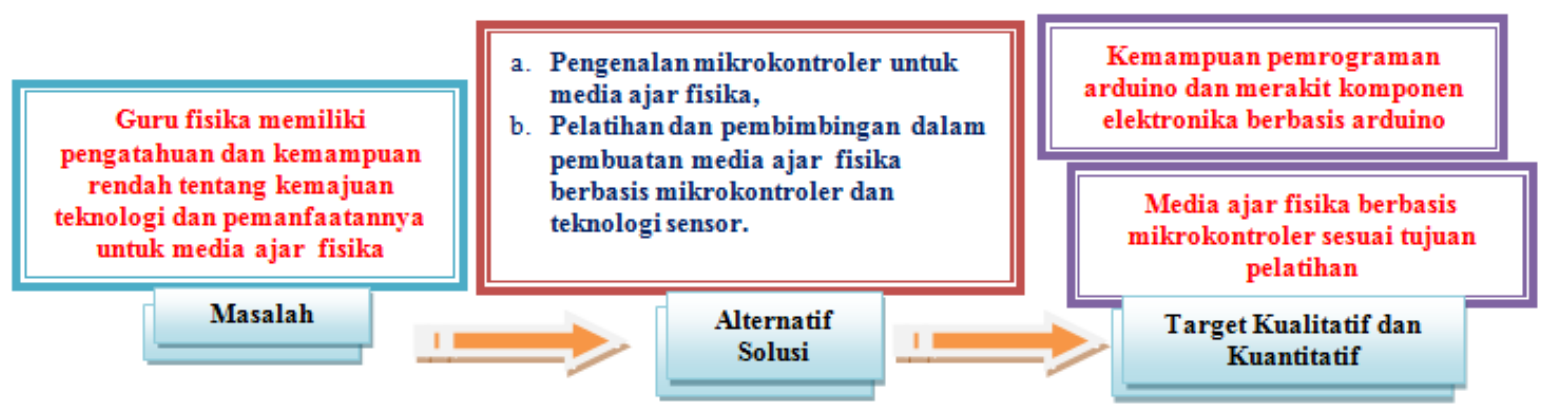

Gambar 1. Bagan Gambaran Masalah, Solusi,dan Target Kuantitatif

\section{METODE}

Metode Sains Teknologi Masyarakat (STM) atau Science Technology Society (STS) adalah pendekatan yang tidak terlalu berbeda dengan pembelajaran disiplin Fisika, Biologi, atau Kimia di sekolah umum. Menurut Akcay, dkk. (2010), "STS is the teaching and learning of science-technology in the context of human experience". Adapun tahapan-tahapan STM menurut Pratiwi dan Nurhidayati (2016) sebagai berikut: Pertama, Inisiasi/Apersepsi, Pada tahap ini pemateri menggali pemahaman seputare-learning dan mikrokontroler yang dimiliki oleh guru fisika. Pemberian tugas dan proyek pada setiap individu yang relevan dilakukan sebelum proses penanaman konsep. Kedua, pembentukan konsep. Pada tahap ini merupakan tahap pemberian materi dari pemateri terkait e-learning dan mikrokontroler terutama pada CMS dan Arduino. Pada tahapan ini, peserta diusahakan mampu membangun atau mengkonstruksi sendiri pengetahuannya melalui observasi, eksperimen dan diskusi. Ketiga, penyelesaian masalah. Tahap ini merupakan tahap selanjutnya dimana peserta mampu melakukan pemilihan alternatif pemecahan masalah dan mencoba mengaplikasikan dalam bentuk tindakan-tindakan konkret terhadap permasalahan yang dihadapi dalam penyelesaian tugas danproyek. Keempat, pemantapan konsep, tahap ini dilakukan berupa eksplorasi kembali konsep-konsep yang 
telah dipahami untuk pemantapan materi lebih lanjut.
Tahapan moteode STM dapat dilihat pada gambar di bawah ini.

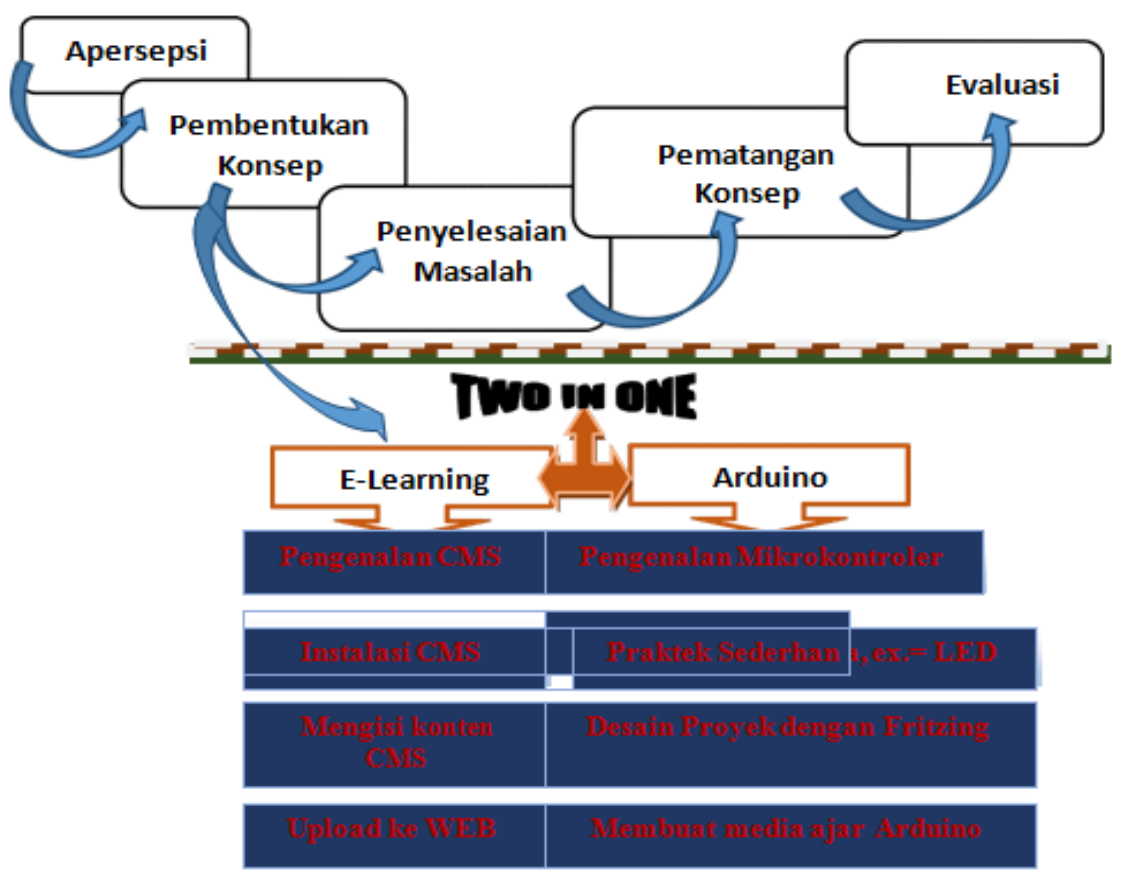

Gambar 2. Metode Sains Teknologi Masyarakat (STM) untuk Dua Materi E-Learning dan Mikrokontroler Arduino

\section{HASIL DAN PEMBAHASAN}

Pengabdian ini merupakan pelatihan dalam rangka meningkatkan kompetensi guru fisika dengan memanfaatkan perkembangan pembelajaran berbasis ICT yag sedang berkembang, yaitu pembelajaran fisika dengan menggunakan media ajar berbasis mikrokontroler arduino, yang dikemas dalam satu kesatuan hardware dan software Two in One.

\section{a. Koordinasi dengan mitra bestari sebagai tahap apersepsi dan tahap perencanaan}

Pengabdian PKM 2018 ini merupakan program pengabdian kemitraan yang bekerjasama dengan dua sekolah SMA di kabupaten Purworejo yang diwakili oleh SMA 1 Purworejo dan SMA Muhammadiyah Purworejo. Kerjasama program PKM merupakan tindak lanjut dan sebagai wujud kerjasama antara FKIP Program Pendidikan Fisika dengan MGMP Fisika Kabupaten Purworejo.

Pelatihan dilaksanakan selama 30 jam pelajaran dengan perhitungan 15 jam pelatihan dilaksanakan selama 2 hari dan 17 jam adalah penugasan proyek dilanjutkan pendampingan. Pelatihan dilaksanakan pada tanggal 21 April 2018 dan tanggal 5 Mei 2018 yang dilaksanakan di SMA N 1 Purworejo ruang multimedia. Pelatihan di bagi dalam 2 (dua) tahap, yaitu hari pertama dilaksanakan pada tanggal 21 April 2018 dari pukul 08.00 WIB sampai dengan pukul 15.00 WIB. Hari pertama mengangkat tema pendidikan dan pembelajaran Fisika beserta apikasinya dengan pemateri adalah dosen program studi pendidikan fisika sesuai bidang kompetensinya. Sedangkan hari kedua rencana akan dilaksanakan pada tanggal 28 April 2018 dengan media ajar berbasis mikrokontroler.

\section{b. Tahap Eksplorasi dan Pembahasan}

Tahap eksplorasi merupakan tahap awal untuk mengetahui sejauh mana pengetahuan dan pemahaman peserta pelatihan tentang materi yang akan disampaikan. Hari pertama dilaksanakan pada hari sabtu tanggal 21 April 2018 sebagai permulaan pelatihan sebelum masuk materi pelatihan. Panitia memberikan 25 undangan untuk guru-guru fisika kepada 25 sekolah di 
kabupaten Purworejo. Dari hasil penyebaran undangan hadir 17 peserta guru fisika, 10 panitia dan 8 dosen Program Studi pendidikan fisika. Acara dibuka oleh Ketua Program Studi pendidikan fisika dan Ketua MGMP fisika kabupaten Purworejo.

Tahap eksplorasi dilaksanakan pada hari. pertama kegiatan. Pada tahap ini ada tujuh materi yang masing-masing materi disampaikan oleh pemateri dari program studi yang kemudian dilanjutkan tanya jawab materi tersebut. Pada tahap ini merupakan tahap pemberian materi dan praktek. Untuk proses eksplorasi pendahuluan dilaksanakan pada hari pertama dengan memberikan gambaran menyeluruh terkait perkembangan pembelajaran dan pendidikan fisika.

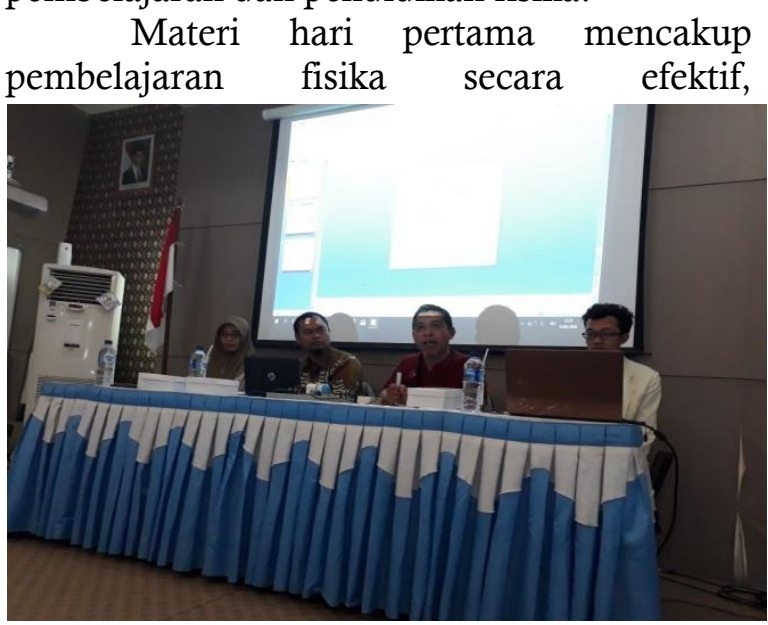

Gambar 3. TIM PKM Memberikan Materi Pembelajaran dan Pendidikan Fisika

Hari kedua pelatihan dilaksanakan pada hari sabtu tanggal 5 mei 2018 di ruang multimedia SMA N 1 Purworejo. Kegiatan pelatihan pada hari kedua yang merupakan materi inti pelatihan dibagi dalam dua tahap, yaitu materi media ajar fisika berbasis arduino. Proses pelatihan dimulai dari proses instalasi software Arduino IDE pada laptop masingmasing yang dipandu pemateri.

Setelah arduino IDE terinstal dilanjutkan penjelasan mengenai pemrogram arduino secara singkat dan dilanjutkan pembuatan proyek. Proyek pertama dengan pembuatan lampu klip-klop menggunakan LED. Proyek pertama masih bersifat sederhana sehingga peserta tidak mengalami kesulitan. Proyek kedua meningkat pada pembuatan media ajar dengan menggunakan sensor suhu dan ultrasonik.

Praktikum pembuatan media ajar berbasis arduino ini secara umum berjalan lancar. Semua target materi sudah pembelajaran fisika dan permasalahannya, model pembelajaran fisika sampai aplikasi fisika dalam teknologi seperti teknelogi wireless dan ICT. Peserta sangat antusias dalam mengikuti materi ini, karena ada beberapa informasi yang belum diketahui oleh peserta seperti pembelajaran fisika berbasis android, hal ini untuk mengatasi penggunaan HP ke arah positif dalam pembelajaran untuk pengukuran berbagai fenomena fisika menggunakan teknologi android. Selain itu teknologi andorid yang dikontrol mengunakan teknologi tanpa kabel sebagai media ajar fisika yang menarik dan efektif. Materi hari pertama secara umum mencakup pembelajaran fisika secara efektif, pembelajaran fisika dan permasalahannya.

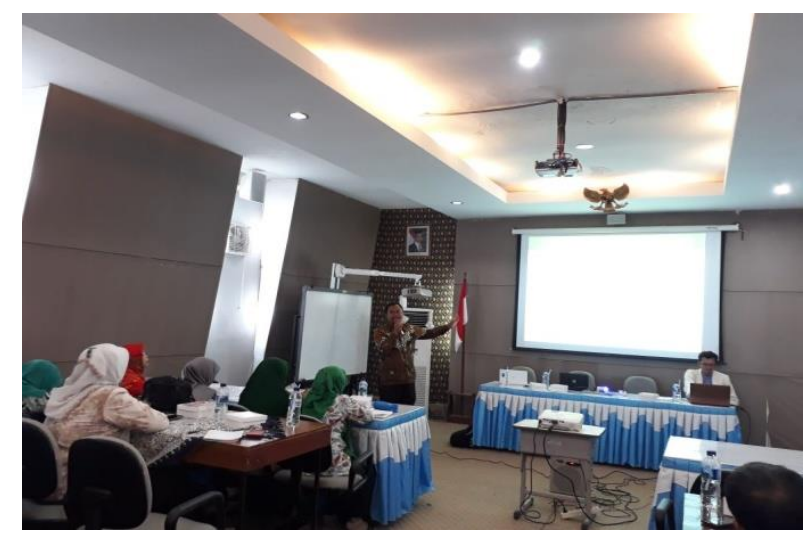

tersampaikan sebesar $95 \%$. Peserta pelatihan merasa sangat terbantu dengan mendapatkan pengetahuan baru dalam pembuatan media ajar berbasis teknologi yang sedang berkembang.

Diharapkan dengan media ajar ini dapat membantu meningkatkan kualitas pembelajaran fisika sehingga motivasi siswa meningkat. Pemanfaatan teknologi sensor yang digunakan untuk membuat media ajar fisika yaitu sensor ultrasonik dan sensor suhu. Pemanfaatan sensor ultrasonik digunakan untuk pengukuran pada materi GLB/GLBB. Materi fokus pada pengukuran jarak dan kecepatan. Sedangkan pada sensor suhu digunakan untuk pegukuran fenomena suhu dan kalor seperti pengukuran termometer dan kalorimeter. Alat yang dihasilkan sebagai media ajar fisika bersifat digital menggantikan alat-alat laboratorium konvensioanl yang lebih presisi. 
Caradde: Jurnal Pengabdian Kepada Masyarakat

Vol 1 No 1, Agustus2018

Beberapa permasalahan atai kendala yang ditemukan dalam praktikum daat terselesaikan dengan alat-alat laboratorium lebih akurat dalam pengukuran, sehingga dapat menghasilkan hasil pegukuran yang lebih akurat juga.
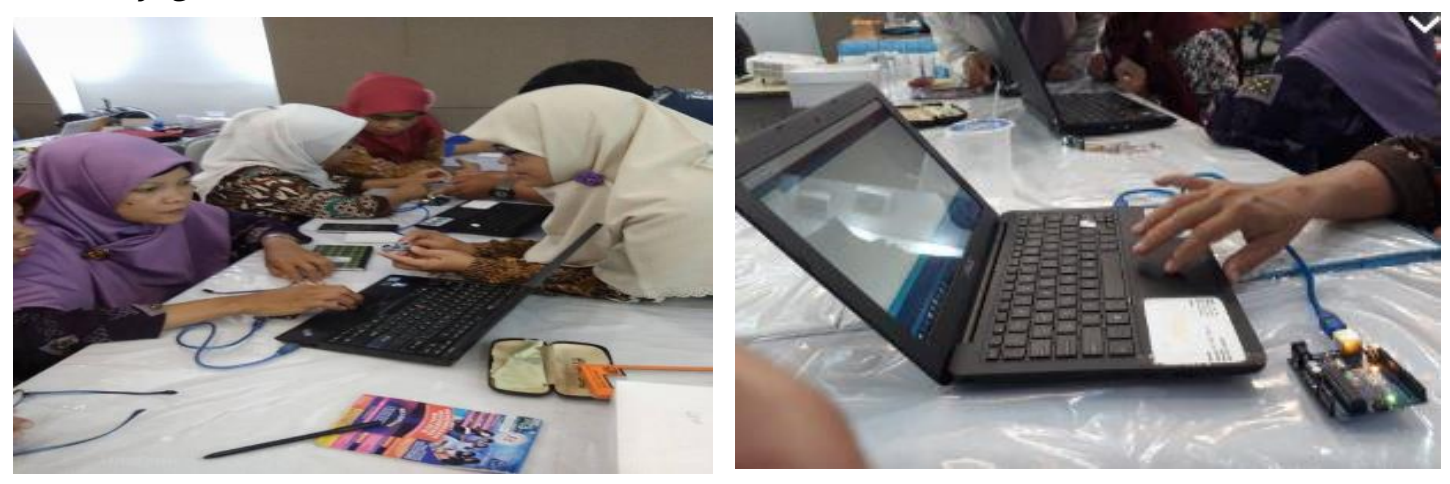

Gambar 3. TIM PKM Memberikan Materi dan Pelatihan E-Learning dan Media Ajar Berbasis Arduino

Hasil observasi dan angket memperlihatkan bahwa materi e-learning mencapai peningatan rata-rata sebesar $67 \%$ dengan fokus pada 3 materi dengan ketercapaian materi $75 \%$. Sedangkan materi media ajar berbasis mikrokontroler arduino mencapai peningkatan rata-rata sebesar $25 \%$ dengan fokus 2 materi dengan ketercapaian materi $50 \%$. Tampak pada grafik di atas peningkatan materi 1 lebih signifikan dibandingkan dengan materi 2. Hal ini dikarenakan tingkat kesulitan antara materi 1 dan materi 2 yang berbeda. Materi 1 merupakan materi kategori mudah, sedangkan pada materi 2 merupakan materi dengan dua pelatihan yaitu pemrograman arduino dan perakitan komponen elektronika. Materi 2 merupakan kolaborasi antara kemampuan software dengan kemampuan hardware. Materi 2 seharusnya diberikan pada waktu terpisah dan tersendiri dengan lama pelatihan yang terstruktur, sehingga lebih mudah dalam proses pembelajaran. Selain itu proyek-proyek pelatihan yang diberikan masih merupakan tingkat dasar belum mencapai tingkat aplikatif atau pengembangan. Namun demikian peserta pelatihan merasa sangat terbantu dengan dibuktikan dari hasil angket yang telah diisi oleh peserta pelatihan. Diharapkan dengan adanya pelatihan ini maka akan terus dikembangkan pelatihan-pelatihan serupa untuk meningkatkan kualitas pembelajaran fisika berorientasi masa depan dan tidak ketinggalan zaman.

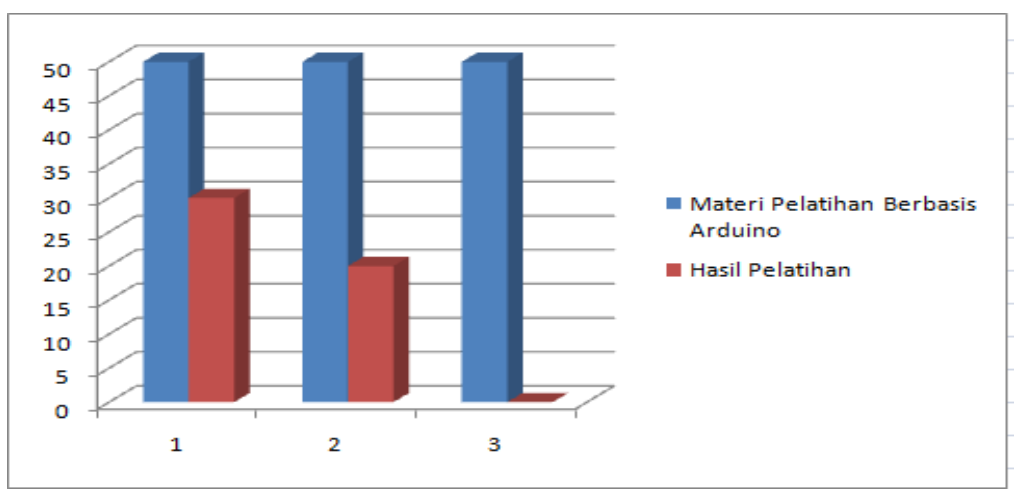

Grafik 1. Peningkatan Kemampuan IT Hasil Pelatihan 


\section{SIMPULAN DAN SARAN}

Simpulan pengabdian yang telah dilakukan yaitu: Pelatihan ini menambah wawasan dan kemampuan bagi peserta tentang media berbasis IT dengan materi media ajar berbasis arduino rata-rata sebesar $25 \%$ dengan ketercapaian materi $50 \%$.

Saran pengabdian yang memungkinkan dilakukan mendatang yaitu: Mengadakan pelatihan berkelanjutan berbasis teknologi untuk meningkatkan pembelajarn fisika dengan bekerjasama dengan sekolahsekolah SMA yang tergabung dalam wadah MGMP Fisika Kabupaten Purworejo dan melakukan pendampingan secara berkelanjutan dan terus mengadakan komunikasi dengan pihak MGMP fisika Kabupaten Purworejo.

\section{DAFTAR RUJUKAN}

Akcay, Hakan, dan Robert E.Yager (1996), The Impacto fa Science/Technology/ Sociatey Teaching Approach on Student Learnigin Five Domains, J Sci Technol.

Anna dan Suwarma. 2015, FilsafatImu, Universitas Terbuka, Jakarta.

F. Bouquet and J. Bobroff. 2017. Project-based physics labs using low-cost open-source hardware. American Association of Physics Teacher Journal. Vol. 85, No. 3, hh. 216222.

Mulichah, Asy"ary. 2006, Penerapan Pendekatan Sains-TeknologiMasyarakat dalam Pembelajaran Sains di Sekolah Dasar, Depdiknas, Jakarta.
Musik, Panjit. 2017. Development of ComputerBased Experiment Set on Simple Harmonic Motion of Mass on Springs. TOJET: The Turkish Online Journal of Educational Technology, Vol. 16, Issue 4, hh.1-11.

Poedjiadi, Anna. (2010), Sains Teknologi Masyarakat, PT Remaja Rosdakarya, Bandung.

Pratiwi dan Nurhidayati. 2016, Penerapan Sains Teknologi Masyarakat (STM) untuk Peningkatkan Kemampuan Pedagogik Guru dan Calon Guru PAUD Kec. Panjer Kab.Kebumen. Journal of Dedicators Community, Vol. 1, No. 1, hh. 82-93.

Rochayati dan Suprapto. 2017, Keefektifan Trainer Digital Berbasis Mikrokontroler Dengan Model Briefcase Dalam Pembelajaran Praktik Di SMK, Jurnal Kependidikan, Volume 44, Nomor 2,hh 127-139.

Risdanto. 2013, Pengembangan E-Learning Berbasis Web Menggunakan CMS (Content Manajemen System) Word press di SMAN 1 Magelang, UNY Press, Yogyakarta.

Warjana dan Razaq. 2008, Membuat Bahan Ajar Berbasis Web dengan Exe, Elex Media Komputindo, Jakarta.

Wijaya, C. A.dkk. 2017. Pengembangan MediaPembelajaran Pengendali Kecepatan dan Soft Starting Motor Listrik berbasis Arduio pada Mata Kuliah Penggunaan dan Pengaturan Motor. JUPITER (Jurnal Pendidikan Teknik Elektro), Vol. 2, No.2, hh. 1520. 